\title{
Editorial
}

\section{Contextualizando a complexidade do processo de} envelhecer...*

\section{Fátima Ferretti, Clodoaldo Antônio de Sá e} Vanessa da Silva Corralo

FisiSenectus. Unochapecó Ano 3, n. 2 - Jul./Dez. 2015 (editores)

Historicamente, as diferentes teorias do envelhecimento com distintas (e, às vezes, nem tão distintas) bases epistemológicas têm sido apresentadas de maneira antagônica ou com predominância de uma concepção em relação à outra, e não a partir de suas possíveis complementaridades. Esse fato tem produzido uma análise reducionista acerca do processo de envelhecimento, com reflexos importantes na produção do conhecimento nessa área.

Se por um lado a contraposição ou justaposição das diferentes teorias e/ou concepções de envelhecimento têm produzido um quadro teórico/prático não muito efetivo no que se refere ao cuidado do ser humano que está envelhecendo, por outro, não se pode negar que esse modelo também tem produzido alguns avanços. No entanto, há que se admitir que os conhecimentos e experiências acumuladas pelas diferentes áreas influenciariam muito mais positivamente a vida dos idosos se o processo de envelhecimento fosse entendido como maior e mais importante que as diferentes ciências que o estudam. Nesse sentido, o debate em torno das diversas teorias e possiveis complementaridades precisa impactar na práxis do cotidiano da intervenção e do cuidado.

Buaes $^{1}$ destaca que compreender as possibilidades que cada ser humano tem de construir suas experiências e aprender a ser e a viver a velhice de forma bem-sucedida implica também em reconhecer os diversos aspectos da realidade social e cultural em que este viveu e insere-se, bem como os discursos construídos historicamente e socialmente pela sociedade em que vive e que atribuem significados a essa realidade. A velhice constitui-se como um período da vida no qual uma série de mudanças em

\footnotetext{
* Ferretti F, De Sá CA, Corralo VS. Envelhecimento: um fenômeno contemporâneo, complexo e multidimensional. In: De Sá CA, Ferretti F, Busato MA. Ensaios contemporâneos em saúde: uma perspectiva interdisciplinar. Chapecó: Argos; 2013. p. 93-112.
}

\section{Fisi enectus}


diferentes aspectos requerem um processo contínuo de adaptação e enfrentamento, com vistas à preservação da autonomia e independência como condições determinantes para uma boa qualidade de vida.

Atualmente, a ideia da velhice como um período de perdas tem dado lugar à compreensão de que os estágios mais avançados da vida são momentos propícios para novas conquistas no que se refere ao prazer e à satisfação pessoal. No Brasil, nas últimas décadas, despontaram programas voltados aos idosos, os quais encorajam a autoexpressão e a exploração de identidades de uma maneira que, até há pouco tempo, era exclusiva da juventude. Contudo, a sociedade parece estar despreparada para lidar com a decadência de habilidades físicas, emocionais e cognitivas do idoso.

A etapa da vida caracterizada como velhice, com suas peculiaridades, só pode ser compreendida a partir da relação multidimensional estabelecida entre os diferentes aspectos do envelhecimento, sejam eles cronológicos, biológicos, psicológicos e/ou sociais². Essa interação é instituída de acordo com a cultura na qual o indivíduo está inserido, com as condições históricas, políticas, econômicas e geográficas, as quais produzem diferentes representações sociais da velhice e também do idoso. Há uma correspondência entre a concepção de velhice presente em uma sociedade e as atitudes frente às pessoas que estão envelhecendo e, nesse sentido, o desafio posto seria de resgatar as teorias para lançar luz às problemáticas atuais no que tange ao planejamento de ações e políticas para o cuidado dessa população.

\section{Referências}

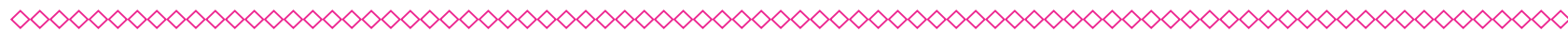

1. Buaes C. O envelhecimento e a viuvez da mulher num contexto rural: algumas reflexões. Rev. Bras. de Ciên. do Envelh. Hum. 2007; 4(1):103-114.

2. Schineider RH, Irigaray TQ. O envelhecimento na atualidade: aspectos cronológicos, biológicos, psicológicos e sociais. Estud Psicol 2008;25(4):585-93. 